FIV: GNA

$\because-2$
DEPARTIENT OF COMERCE

BUEEAT OI STANDARDS

WASHINGTOIT

August \&, 1933
Letter

Circular

LC $-33^{\circ}$

\title{
THE CARE OF FIOORS
}

Contents

Page

I. Introduction .............. . 2

II. Precaution ................ . 2

II. Wood Iloors . . . . . . . . . . . 2

IV. Floor waxes or polishes ........... 5

V. Cement (concrete) floors.......... 7

VI. Vitrcous tile or ceranic ana terrazzo floors. . 9

VII. Marble and travertine floors......... 9

VIII. Linoleum floorings . . . . . . . . . . 11

IX. Rubber floors ............. 12

X. Cork tile and cork carpet floorings ..... 14

XI. Asphelt tile and mastio floors ....... 16

XII. Plastic magnesia cement floors......... 16

XII. Slate tile floors . . . . . . . . 17

XIV. Refurences .............. 17 



\section{IMTRODUGIION}

The following information, although it was not gained by an experimental study, was gathered from reliable sources and experience, anc has veen reviewed by verious authorities on the maintenance of flooxings.

\section{PEECAUTION}

Gasoline, turpertine, acetone, and many other volatile organic solvents are very Slanmable. Care should be taken in using those solvents or piecantions contrining them to have good ventilation ano to avoid open lams or smoking in the rooms or other spaces. oily and gressy rags should be inmediately destroyed aftor using or hept in closed metal contoincrs. Animal ana vepetrole oils are the most likely to ceuse spontaneous combustion.

\section{WOOD FIOORS}

Unfjnished wood foors silould be nopped or scrubbed with warm water and a mila soa. Scouring with powdeced punice or steel wool my be desirable in some cases. A solution of trisodium phosphete, sodiun metasilicate (wout $1 / 2$ oz. per gellon of water), or washing soda (about 2 o\%. per galion of water), may be used ror clo ning oily or greasy floors. After using soap or other cleaning agent, tile floor should bo thoroughty rinsed off with clear water and wiped as ary is possible. It is ditis ble to scrub a small area at one time and to avold floodine the floor with cleaning solution or rinse water. Strong solution of soaps, alkalies, alkaline selts, and the too free use of wator nay darken wood and my in time softon it ard rase tro grain. Oak floors are readily darkened by stronglkaline solutions. Whero wood is brily stainod or discolored, bloaches (such as oxalic acid solution; oxalic acid is a poison if taken inturally) may be used, or the floor hay be screpod or machine sanded.

Varnished and shellacked floors should be dusted clean rith a soft brush or dry rop, wd thon rubied with an ojled mop or a cloth slightly moistend with floor oil, kerosene, or furniture polish. In enerel, varnishod and sholiacked surfaces should not be treated with weter, but if bady soiled thoy my be wiped with a hop or cloth wrung out of warn, slightly soapy wator, then wj.th a rae or mop moistened with cleor woter, wiped dry at once and polished with an oiled mop or cloti. The appearance of bady worn varnished wood may be improvea by ribing with a floor wax.

oiled floors and pinted floors should be swept with a soft brusi end thon rubbed with an oiled mop or cloth. Occasionally, they nay be weshed with slightly soopy wator, rinsed off with a wet cloth or rop, wiped dry nid then polishod with an oiled mop or cloth. 
Waxed flloors may ie cluned with s oft brush or mop free from oil since oil softens the wax. The film of dirt and wax which darkens the surface nay be renovea ith a cloth wrung out of warm soapy water. The use of a rag moistered with gasoline or turpentine would be a better and more rapjd procedire; however, these liquics are very flameble and care should be taken to avoid having open flames in the rooms. Gasoline and turpontine brighten as well as clcan tho surface, whercas rater dulls and whitens wax. If a vatex-cleaning mothod has wliendy intoned a waxcd floor, the luster and color mey be restorca by rubbing with a woolon. cloth or a weighted brush; if nocessaty a ittio wax may be apolica. Manj kiras of spots or waxea floors may be removed by rubbing with a little turpontine or gasoline and refinishing with a very thin coat of wax. The cntiro coating of wax (and dirt) can be renoved from wood floors by rubbing first with number 00 steel wool aipped in gasolino or turpontine and then with a soft. cloth, after which the floor nay be refinished.

Varnish or peint can be removed from a rood rloor by scraping and planing, or by applying a paint and varnish renover. The first method, aIthough tedious and laborious, is the bottor and is necessiry if the floor hes beon strinca." Arter a floor heus becn scruped, plancd, and scripapored, it can be finished as though it were new.

Romoving peint or virnish from floors rith paint and varnish removers must be done. oerciully so as not to darage the finish on baseboards and wolaings. The comercial. "solvent type" of paint and varnish renovors are satistactory for this purpose and are labeled ith instructions for using. A solvont type of paint snd varnish renover my we prepared as follows:

Dissolve 3 parts of peraffin ( $i$ i shivings) in 50 parts of benzol, then ada 25 parts of aenatured alcohol and 25 parts of acetone.

After this rixture has been appied to the surface with a brush and allowed to stind for a few minutes, the paint or varnish will soften so th t it can be scraped off with a putty knife or rubbed off with steel. wool or excelsior. When a putty knife is used as a scraper it will prove more effective if the end of the blade is ground to a shap edge. By holding the putty knife in a vertical position and scraping across the grain of the wood, there is no danger of splintering the floor. This peint and varnish renover and others of this type should be used only where there is good ventilation and rio open flame of any kind, as they contain highly flamable materials.

Coustic soda or houschold lye solutiong are also uscd for removing paint and virnish, but should not be usca on ogk, floors. These solutions shoula bé handled with crie and not allowed to cone in contact with the skin, clothing or surfaces other than the one being treated. Rubber gloves should oe worn. The caustic 
sode or lye mey be dissolved in plain viter and the solution applied wile hot, out better rosults will be obtained if the crustic socic is nixed withe. starch solution, such dz is used in starchirg cloties. About 3 or 4 tablespoons of carstic soda cre generally added to one part of the strroh solution. Inis mixture is rpplied wilile int to tre. floor, using a cotton brab, a fiber (not bristlo) orush, or a lons-handled scrubing brush. After a fav ninutes the sortencd paint or varnish moy be scraped or ruibed off. me floor should tinen bo washad scveral timos with clon vater, allowod to dry thorouginy, snidpaperod or rubod snootin, ind dusted bofore it is refinished.

If shellac varnish alone has been used on a floor, it con be romoved bj flooding a small wea at $\theta$, time witin donetured alcohol and, aftor a fon kinutos, mabirg titr stecl tool, or scraping as cuburc.

In reinising an old rood floor, it is firet made as tight, level, and swooth as possikle. It my need to be plened, sandpepad or rubbed dow ith s.teol wool. Any remants of tecks must be drawn or drivon bolow tho surfaco. Then scrub tho wood with. hot weter and soap or othor dotorgent and rinse with clear water. If the rood is bodly stainod, spreso over i.t a bloach solution mado by dissolving a teaspoon of oxalic coid (poison) in a cup of hot wetor, and let stand overnight. Then thoroughy rinso the floor with clenr vatur to remove all of the bleach (and cloaning agents) and lot dry. The thoroughly dried floor may be staincd, varnished, oiled, peintod, or waxed. After applying the Iirst cont of finish, it may bo nocossery to fill cracks sid holes with a comercial "orack riller" colorcd to metch the floor.

Romoving old finishos frow wood floors and refinishing them is hard work nd in wost cases it would probajly be moro satisfactory and conowicul to heve this work done by an expert, who has the proper tools and knowis just hor to treet different woods.

After cleaning and dryin, wood floors are generally raxed. Floor mx should oo coplicd in very thin coats and thoroughly rubbed mith a hoovy vaxine brush or motor drivon brush, or a heavy block wrepped in burlap or carpet. In propering a new or refinishod floor for waxing, it is comon practice to epply o coat of shollac virnish or other quick-arying varnish Doforo vexing. If this is done it is better to havo a vory thin coating of shollac, as thicker coatings aro apt in timo to crack or peel, which vill nceessitote complete refinishing. The wex can be applied airectiy to close-greined woods such as maple or pine, or to such open-erained wood as onk, if a "silichte nood fillén" is first appiea. This treatment requires more waxing, and therefore more lavor, in the original job, but the finish is likely to be more ourable. However, floors finished in this way often arren wore readily thon if the wax is applied orer a thin cost or shellac. 
IV. FLOCR TAXES OR POTISEDS.

The following formulas, given in Bureau of Standards Letter Circular No. 275, furnisi good floor waxes or paste polishes:

In maing oither of the following waxes be viory careful to heat only by setting the vessel containine the vaxes in hot water and to have no flumes in the rook, sine boti gasoline and turpentine are very filamable.

(1) Material Purts by weight

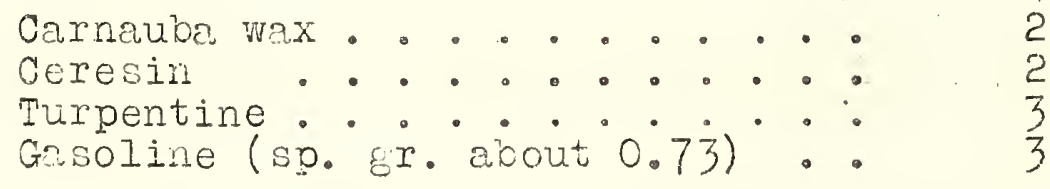

Melt the waxes by heting in a vessel placed in hot water, add the turpentine. cond gosoline and cool the mixture as rapidiy as possible, wile vigorously stirring to produce a smooth creamy $\max$.

(2) Turpentine Beesmax Aqua rinonia $i(10$ per cent strength) 1 pint 4 ouncias water........... about 1 pint

mix the buesmax and turpuntino and heat them by placing the vessel in hot water until the beeswax dissolves. Romove the mixturo from the source of ho t, add the amonis and the water, nin stir vigorously until the mas becones ereany. This wax should be applied lightly on vanishod or shollacked floors and any excoss wiped off at once, as the amonia may attek the varnish or shellec. When this wix is uscd on unfinished oak flooring; the annonia may causo a slight darisening of the wood.

The nower water-wax cmulsions, comwonly colled non-rubbing liquid maxes, aro now videly uscd on wood, cement, linoleum, rubber tile, cork, aspult tile, mostic, and othor floorings. Many of these preparations ary rapidly and requirc little or no polishing. These wter-wex cmulsions usually consist of carnauba wax (and othor wXos) aisperscd in a weter solution of soap. Somotimes cmulsitying decnts othor then soap are uscd. A small amount of resins is often used in prepring those crulsions. Synthotic as well as notural productis nay be used in some of these preparations. A simple cornauba wax-soap-water emulsion ma be prepared or experinental purposes as follows:

Dissolve l part by weight of castile soap in 16 parts. of clean, soft water, and heat the solution to boiling. Add to the boiling soap solution with constint stirring it parts by weight of 
a good grade of carneuna wu (cut into smal pieces). When a smooti honogeneous emulsion is obtainod, cool to a temperature of $135^{\circ} \mathrm{F}$ by quickly adoing, with cons'unt stirring, the necessory quntity of cold water. (Tisis. should trike about 14 to 16 parts more of wator). Let cool, tilter throuch cheese-cloth, and stir in about 0.5 per cent of formaldehyde as a preservative. The product so obtained should be ot the color and consistency of cream. A thicker or thinmer product my be made by decreasing or incroasine the quintity of watcr used, taking care to maintain the given ratio between soap and wax. This wax mixture may require polishing or buffing after arying in order to obtain a glossy surface.

The following information ard formulas for the proparation of a "triethanolamine-carnauba, wax ary-bright polish" have been furnished by a manufacturer:

"Shellac has been incorporated in this polish to cut. down the slipperiness of a stright carnauba wox emulsion. A dry bright polish can also be made as directed by merely leaving out the shollac solution and adine the vator used in it to tho wax emulsion. The adition of the shellac seems to make it spread more everly and, as stated, makes a film that is not quite so silppery. It is necessary to use good grade of light oolored carneuba wax (known in the trade as: "No. I") and tre directions for maling the polish must be carried out as described. The temperature should never be above $100^{\circ} \mathrm{C}\left(\mathrm{2} 12^{\circ} \mathrm{F}\right)$ at any time."

The polish is made as follows:

\section{Irial batch Larse batch}

Carnauide $\operatorname{rax}$

oleic acid

Triethonolomine

Borax

Winter (boiling)

Shellac (ary flakes)

Amionia ( 28 per cent)

Water. (room temperature)

*milliliters (ml)
13.2105.

1.6 pints or 1.5 1.b.

1.9 pints or 2.1 lb.

1.01 .

$11.5 \mathrm{gal}$.

$2.21 \mathrm{bos}$.

0.35 pint or $165 \mathrm{ml}$

2.0 gals.

(1) ivelt the wax and add the cleic acid. Temporature should be about $90^{\circ} \mathrm{O}\left(194^{\circ} \mathrm{F}\right)$. Placing the container in boiling water keeps tre polish at a sood temperature. 
(2) Add the triethentamine slowly, stirring constantly. This should make a clear solution.

(3) Dissolve the borax in aoout $5 \mathrm{~m}$ of the boiling water and add to (2). Stir for ebout 5 minutes. This gives a clear, jelly-like mass.

(4) Ada the rest of tho boiling water, slowly with constant stirring. An opaque solution should bo obtained. Cool.

(5) Add tho $100 \mathrm{ml}$ of room-tempersturo water to the shellac and then the amonia and heat until the shellac is in solution. CoOl.

(6) Add the shellac solution to the wax solution and stir well. The resulting solution should give a clear film when applied to linoleurn, mastic floors, etc., and one that is not too slippery.

\section{CEMEIT (CONCRETE) FLOORS,}

Unpainted cement floors may be scrubbed with hot water and a scouring powder, or with hot water ana washing soda (laundry soda or "modified soda"), sodiun metasilicste or trisodium phosphate followed by scouring powder. The floor should first be wetted with clear water and then with the hot solution of washing soda (about 2 to 2 l/2 oz. per galion of vater), sodium metasilicate or trisodiun phosphate (a bout $1 / 2$ oz. per gallon of vater), sprinkled uniformily with the scouring powder, rubbed or nopped, and then rinsed thorougily with clear water to remove alkaline solts and scouring powder. The use of soap on unpainted or untreated coment floors is not rcommended as a scum of lime soap ma be formed on or in the surfece of the floor. Painted cement floors should be wshed or mopped vith plain woter. If very dirty, a slightly soapy wter might be used, followed by thorough rinsing with clear water, but such treatment should not be used as a general or frequent procedure.

occasionaly cerient or concrete floors are waxed. The waxes comimonly used on wood floors can be used on painted or unpainted cement floors. As these wixes generally vary in color from yellow to brown, they should be used speringly, as any wax or oil that ma penetrate into the floor will tend to darken it. Waxes have been applied in a molten condition. to unpainted or untreated cenent floors as a special floor treatment. (sec Letter Circular No. 139 referred to below), but this troatnent is not in general use. Recently water-wax emulsions (such as a mixture of carnauba wax and resins dispersed in vater) have been put on the market for polishing cement floors and preventing the "dusting" of such 
floors. Wax treatments also make the floors water-repeliant. Concrete or cement surfaces with deposits of oil or grease, such as driveways and the floors or garages, shops and engine rooms, may be cleaned with sodiun metasilicate powder (about 4 oz. per gallon of water), trisodium phosphate (about 4 oz. per gelion of water), or a mixture of 60 par cent trisodium phosphate and 40 per'cent soda ash (about $1 / 2$ to 1 Ib. of the mixture per galion of weter). An abrasive powder: (scouring powder) mey be mixed with the bove solutions. These detergents should be used with very hot water and the surface might be rubbed vith a wire brush, or an abrasive powder and a mop. If the deposits are thick and of lorg standing, the powated detergents mey be sprinkled over them and moistened with a little water; after standing about $1 / 2$ hour the surface should then be scrubbed, using very hot water. After scrubing, the surfaces shoula in all cases be theroughy rinsed with plain water. Instead of the foregoing treathont, the cil and grease can be mopped off with kerosere and the mopod neas covered with a layer of sawast for a iew days. After sweeping off the sewdust, the surfaces can be further cleaned with the above detergent solutions if necessary. The following procedure has been found effective in removing old oil stains: fiirst scrub the surface with a hot solution of trisodium phosphate (about 3 to 4 ounces per gallon of water), using an abrasive rowder with the solution is there is a dark colored film on the surface. Then mix whiting with some of the not trisodiun phosplate solution to form a thick paste; cover the stained area in the paste and leave until dry; scrape off the dried paste and rinse the surface with cledr, hot water. Repeat this poulisice treatment if necessary. In tine case of barly soiled concrete or cement floors the appearance may also be improved by sprinkling over the scrubbed floor a layer. (about $3 / 4$ inch thick) of dry hydrated lime, allowing to stand for soveral hours, and then removing the covering layer. In sone cases it maj be desirable to repeat the vashing and the dry hydrated-lime treatment several times. Fine, dry coal ashes may be used instead of the hydrated lime. Solvents, such as carbon tetrachlorice or a mixture of carbon tetrachloride (2/3) and gasoline (1/3) could be effectively used on the washed and dried floor in conjunction with the hydrated lime or ashes, but this would be quite expersive.

Some years ago the Bureau nade tests of various treatments to prevent excessive wear and dusting of concrete floors and for holding the cust produced by wear or abrasion on such floors. These tests are described in Letter Circular 10.139 on "Report of Service Iests on Concrete Floor Treatments". A copy of this letter circular may be obtained free of charge upon request to the Bureau of Standards. 


\section{VITREOUS TIIZ OR OERALIC AND TRRRAZZO FLOORS}

It is good practice to clean these floorings periodically with a vacuum cleaner. Tho routine vashing of these floors is usually carried out by first wetejng then with clcar water and then moping fith hot water containing a small quantity of an alkaline clcaner, such as washing soda (about 2 oz. per gallon of water), trisodium phosphite, or sodium metasilicate (about $1 / 2 \mathrm{oz}$. per gallon of water). Eadly soiled areas on the floor may be cleaned with a scouring powcer or a little scouring powder may be sprink]ed over the soiled areas before applyine the alkaline cleaning solution. Occasionaly, the entire floor should be scrubbed with a scouring powder or with an alkaline cleaner and the scouring powder. A motor-driven scrubing machine is a desirable appliance. After cleaning, the floors should be thoroughly rinsed with plain water and wiped dry. If vater is left stending on a tile floor it might loosen the cement that holds the tiles in place. Soaps are not gencrally used on these floors owing to tho tendency to "build up" slippery filns, especially if the water is not soft or the rinsing has rot been thorough. However, such floors are sometimes wiped up with a cloth wrung out of hot, soapy water, rinsed off, and wiped dry. If soft water is used and the surfaces are thoroughly rinsed after cleaning, it is believed that soop would be satisfactory, but hore expensive, for the routine oleening of these floors.

\section{WARBLE AND TRAVERIINE FLOORS}

Travertine floors should be first clesned with a vacuum cleoner ond then treated the same as terrazzo floors. It is good pr:ctice to clean mable floors periodically with a vacuura cleaner. In cooperation ith the National Association of Marile Dealers, the Bureau of Standards has made o study: of the maintenance of interior marble. A report of this work was published in 1927 as Bureau of Standards Technologic Paper No. 350, entitied "A Study of Probiems Relating to the ilaintenance of Intelior Marbie". This paper is now out of print, but it con be consulted in many libraries. The following conclusions are reported in the paper: (References to polished. marble do not apply to floor tiles).

"I. Various cleaning preparations have been atudied with a view of determining the effects on marble of certnin ingredients from a long period of use. The laboratory experiments, es well as an examination of ectual installations of marble, have indicoted that injury may result from injudicious use of harsh grits or from such salts as sodium carbonate, sodium bicarbonate, and trisocium phospinate. 
"2. Tí usual trpe or exit onployed in trode cloonin prepuritions is not apneciowly injuriois to morole flnors or other unpolished mrole. Polished. mible whould raiely be clenned vith properations containing couring gent or abiasive which is harder than the mariole.

13. As a rule, the volonic ash grits are less severe in their abinding action thar crushed puertz. This is evidenty due to the difference in shape of the particlos.

14. While it is seldon if ever necessary to use a cleaning properatjon of tine scouring type on polished narble, when it is in stock for olconine tho floors of $a$ building it is npt to bo wrongly uscd on tho polishod mablowork. For this rooson de. propsration of tine type is dosirable winch has a grit thot will not injure polishod mrile. Availablo wincrals mich scon to moot this requirement aro sorjotone and teils.

"5. A trial preparetion consisting of 90 pir cent poweicred sorpstone and 10 per cont soap powder apposica to be as cifcetive in clewing mrio floors as ariy of the presont trade pereparations. Such a conposition can we used on polishod mable without aprecieblo injury.

"6. Injury which ny rosult from the froquent uso of such dotergents as sodiur carbonato, sodiua bicrrboneto, or trisodium phosphate is malniy a physicel cifect duc to thesc salts crystalizing in the pores. This notion has beon dewonstreted to be severe encugh to cause disintegration of marble when such salts are employed without proper pecautions.

17. Experiments have incicated that marble nork may be safely cleaned ith such dotorgents if the wrace is rinsed with clear vater before applying tic cleaning solution.

"8. Althouk soap has been found objectionable for use on arable in certain instances, the prisent study has indicated thet if uscd ith soft wetcr it. vill give ontiroly satisfactory results and prove to be tho sufest detergent for general sorvice.

"9. Pleparations conteining a coloring ingredient of different color than the marle may gradually impart their color to the mrble. Mis, hovever, may be prevented by a prelininory rinsing, as described in conciusion 7 .

"10. Amonid weter has been used to some extent in cleaning polishea marb]e, but a linited number or teste in this investigation have indideted that it way curse yellow discolorations. 
111. Aojds dissolve mrole, and even the use of such weak acicis as oralio will prove injurious. Although cleaning of interior warblo with acids nas been pratticed to sone extent, it is usully done trrough ignorance of the real effects.

"I2. Staing which have penotrated the marble usually have to De renoved by weans of a poultice troatmont. Sevcral types of stain domand specisl trentmont, nd thore is no singlo curo for all cases. Methoss heve been found for eradicating practically all of the comon stains ocourring on interior mable."

An abstract of Technolonic Foper Ho. 350 has been published as a booklet, "Haintenance of Interior Mrble", by the Notional Association of Marble Dealcrs, 721 Rockefeller'Building, Gleveland, Ohio.

\section{IINOLEUN FLORIMGS}

Untreated Ploorings should be swept dajly with a soft floor brush or on oil-tronted mop. Anything spilled on the flooring should be wiped up as soon as possible with a danp cloth; and occesionally, as the flooring needs t.t, it sinould be washed. Care should bo exercised in whing these surfeces. Proparations containing free alkali, nkaline salts, or abrnsives should not be used. The safest procedure is to use c. Iukevarn solution (solt wator) of a mild or noutral soop ind to rinse all soapy weter off with plain soft water after whing. The surfaces should bo finally wiped dry ith mops or cloths. Care should be tnken not to flood tho surfeces with veter, since any watur that scops through the eages ur soms hy affect the comenting matrial and my cause the burlep becking to mildew or rot. Linoloum in kitehens, pentries, or entries will look briehter and wear better if the cloan, dry, unwaed surface is givon an occasional cort of a prle, quici-drying lacquer ("Iinoloun Lacquor"). Nover lacquer over wax. The lacquered. surface after drying my be waxed, out this is not generally done. The lacquered surface wy be cleaned daily with a dust mop or, whenever requirea, with donp cloth. These floors should be relacquered occasionally, depending upon the severity of vear.

In rooms or places were the wear on the floors is not particularly heavy, the clean, dry linoleun should be waxed and polished. Any good floor wax is suitable for innoleum. A wax prepared according to formula (I) on page 5 is satisfactory. Paste wax can bo usca but "liquid" wax is easier and nore economical to apply. The nowor water-wax emulisions (see p. 5) are elso uscd. Care should bo taken not to put the wax on too thickly as it is likely to smear and give a greasy appearance to the floor. Too much wr will cause the floor to be slippery. After applying the ma, it should be polished for some time with 
a veighted floor brush or on electric polishing mohine. Daily care of a we.lI-wned and polished floor should consist in going ovor it utin a ary dust-nop. Weshing is eeldom necessary - perhaps two or three times o yenr. Waxing not only adds to the appearnnce of the linoleurn but provides a wearing surface and protects tre floor. An occasion? polishing. my be necessary on the main traveled arees: Rewaxing will be required from time to time de ending upon the mount or trific. Depenaing upon the service conditions, the floor may require scrubbing t times, after wich a coat of hew wh should be applied. "Linoleum tilo" floors, nnd linoleun floors subjected to mon wear, should be given one or tro coats of. 0 linoleun lacquer and then woxed and polished. After the wax ho,s diied for a short time on the "tile" floors, run a polishing machine equirped with a finc-bristled brusk over the flloor in botr gjecticns in order to work the wax into the surface. Swrep off any dust or wax particles and polish iti an electric polishing mochine. Lncquered and woxed floors should be cured. Fon as outlined for surfaces that have been waxed directly. Before lacquering an olá lineolum or "Iinoleum tile" floor, it must be thoroughy cleaned with $a_{\text {c cloth }}$ dempened ith gasoline and frequentiy squeezed out in rresh gasoline auring tre cleanilig, jn order to remove all grease and wex. Thon the ontire floor should be scrubed with lukewrm sonpy water, rirsed thopoughy with nlain water, and allowed to diry.

Tho life of a linoleum floor covering oan bo prolonged by applying a pale, transparent vomish but this troatmont is not recommonded, as many varnish corting becomo sijghtiy yellow. This mas the design effect in petturne and mey produce a decided aiscoloration ovor plein surecos. Somo varnishes will turn white when water is spilled on then. The seme objections may apply to snellac. Floor oils end swooping comounds contrining ojl. should not be lisca on linolcum, as theso materiels may lcava a filin of oil on the surface to collect dust and dirt. Varnished surfeces can be waxca to produce a "dull polish".

\section{IX, RUBBER FIOORS}

To clar unpolishod floors, brush off looso dirt with a soft push-broom and mash a sull section of the floor vith a clean mop wrung out of a solution of washing soda ("modified soda" or 'Inundry soda) or trisodiun phosphete (clouit a quinter of a cupful of the clenner dissolved in 12 to 16 quarts of clear, cold water). Clenning mey also be done by mopring ith cles, cold water containing 2 to 4 ounces of ordin ry household cinmonia per gallon. Finse the mop in a second peil of clear, cold mater, wring the mop, and wipe the section of floor clean of'solution. Continue this process until. the entire floor is cleaned. After the floor 
has dried, buff it thoroughy ith a rotary electric buffing nachine (for large areas) or a weighted hand bufeer to which a piece of rough cajpet or similer matericil is attached as a buffing surface. Daily cleuning an often be satisfactorily done Dy sweoping ith a solt, ary. brusk, or with a soft pushbroom, and an occsiongl washing ith culewn mop wrung out of clear, cold water. When very dirty, the floors should be cleaned with s. wasing solution as outlined above. Frequent systenotic buffing of unpolished floors materially reduces the number of reshings required, owing to tho developincht of the bright-dryine wax-water onilsions (polishes) frec from oils, fats and organic solvents, it is now general proctice to polish rubber floore. The waw or polish onchences the appearance of the Iloors and prolongs their life. After cleaning, drying, and buffing as outlined above, the floor is ready to polish if all dirt and harks have been removed. Pour the polish into a shollow receptacle, aip the applicator* into the polish and apply

*

irde of lamb's wool, soft wbsorbent cloth, or felt. The felt applicctor, made of 4 or 5 otilps of $1 / 2-i n c h$ tirick felt stood on eage and bouna tosether, is very satisfactory. Applicntors are gererally iurnished by polish manufacturers.

a thin cont over a simell ares with n wiping notion. Do not rub hrifd. Repat until the entireffloor is covered. Let dry until hra (about 30 minutes) and then buff. Immeditily apply a second thin cont, lct dry, and again buff thoroughly. The polish should be applied in as thin coats as possible to avoid streaking and at leest two coats should be applied. If the polish wears of in cortain scotions of the floos, clcan anc repolish only thesc sections rather.then the entirc floor. Systematic buffing reeps the polished. floor in sood condition and reduccs the number of wasings required. When the polished floor becomes soiled, remove the loose dist wth a soft brush or a soft push-broom and ipe tile floor with a clean mop dampened with clear, cold witer. Mhis treatment should not remove the polish. If this procedure does not clean the floor, it should be tieated as outIined above, using a weshing solution. When necessary, the wax or polish can be renoved from rubber floors vith 2 solution of trisodium phosphte in warn water (about 2 ounches per galion) with the aid of 00 steel wool. The addition of a sinel qunntity of houschola amonia to the solution will hasten the removal of the $\operatorname{vax}$ (end dirt).

Strins my be romoved Irom rubber flooris by rubbing the strined aree with a fine norasive powder or with number oo stcel wool. If this is ineffective, tise spot may be rubed carcfully 
With a clean cloth dampened with acetone (flarrable), gasoline (flommible), or corbon tetrachloride (non-flammble). Gasoline, scetone, and carion tetrachloride have a softening action on rubber if in contact with it long, but the softening is not permanent.

Cleaning materils containing oil (certain swoeping compounds and other detergonts) and coarse abrasivos, or caustic alkoli should not bo used on rubbor rloors. Sowp ma soften and swell rubbur flooins. Although this effect is mininized with careful rinsing, the safost procedure is to sold the use of any soap. Waxes or polishes containing oils, fats, or organic solvents should not be used. Do not use hot vater or cxcessive mounts of water whon cleaning rubbel floors. The floor should not bo flooded with water. Avoid using more of the cleaning compound then specified and thorouglily mop or rinse the surface in order to renove all of the cleanin solution. Rubber floors should not be varnished. Bufinge mohines should not be used for scrubbing rith vater and cleaning cgents. The advice or recommendation of the manufacturer of the rubjer flooring should be secured before using unknown cleaning preparations or applying untried methods.

\section{CORK TILE AND CORK CARPET FLOORINGS}

Inny cork floorings are installed without chy surface treatment other thon sanding. to $\Omega$ smooth surface. These floorings are comonly referred to as "natural" cork and often may be cleaned by dry sweeping with a hail floor brush. The entire surface is tien buffed or polishedititis suitable pads, a polishing machine or a floor-polishing brush. Care siould be taken to overlap tho polished sections. If the floor can not be cleaned in this manner, it should be swept with a soft brush and then moppod with a lukewarm soapy solution made with a mild or noutral soap and clean, soft water. A separate container of clean, lukewarm, soft water and a separate mop should be usod for rinsing. The rinse watcr should bo changed froquently, so that both rinsine watix and mop are always clean. Only a small area (say about $50 \mathrm{sq.1t}$ ) or looring should be washed at one time and it should be thoroughly rinsed with clean water and wiped dry. Weter should not be left on the floor.

Where cork flooring is subjected to much heavy and dirty traffic, it should be varnisied with a pale, transparent spar varnisin, and then waxed and polished. with cork tile it is good practice to spply a filler before varnishing. The varnish usually requires overniglit to dry. A dull or mat finish ma be secured in place of the glossy varnish by scrubbing the varnished floor with a neutral soap and vater and rottenstone or inely 
powcered puice. These treatmenta form protective coetings, but the tre ted floor regriro careful and frequent attontion. The floors should be washed olean and allowed to ary thoroughly before applying filler, varnish or wx. The waxes used for linoloun may be uised' on oork thoors. Liquid floor wax is gonorally, used and is oppliod in a thin, ovon coat and rubbod in. Whon the wix is nearly dry (tacky), briy a second coat of wax in the sume manner. When the second cont pecones trocky, polish tholoughiy with a polishino mochine, a reighted brush, or a clean soft cloth. Mhe apperronce of the surface improves with frequent polishing. The never meterux emulsions the dry rapidy and require little or no polishing nre niso widely vsed for waxing cork floors (see p. 5).

Waxed cork floors are cleaned by rubing with a dry nop or polibhing brusk, pollowed by sweeping vith a brush or a vacuun oleaner.

A polishing machire is a useful appliance soi large areas. cork floors should be polighed or buffed with a brush or hachine whonever they appar duIl or dingy. The floors should be rewexed eror time to tiwe, deponding on traffic conditions and exposure to ajrt. whe flocrs whould be rewaxed before the old wax is worn off. Aruss (doorways, traffic lanes, otc.) subjectod to the most wear hey de rewaxea wilen necessary without going over the entire floor. Before revaxing the floor all wax must be removed by rubbing the surface with a cloth dampened with gasolime (flamable), followed by vigorous scrubing with warm water and soap, rinsing with clean water and crying. If this does not renove the wax, the dried surface should be rosanded.

Lacquer suitabie for linoloun hay be usco on cork floors in liou of waxing. The surface should be thoroughly cloaned and ariod before applying the lacquer. Tivo or three coats of lacquer are used for the first treatnent in order to fill thepores of the flooring and bive a smooth, dirt-resistant surface. Further coats nay be applied as the apearance requirss. "Natural" cork floors which have been varnished may be kept clean by sweeping with a dust-nop, sort brush, or a daip cloth or mop.

Stains and spoti mey be ronoved from cork floors by rubbing with fine mery paper or nuber 00 steel wool. In some cases the spot or gtoin wey be rubbed with a cioth climpened with acctone (flammolo) or with carbon tetrachloride. Tho cleaned arens should then be buffed and. wxed, or varnished and then waxed. 


\section{ASPEALT TILE AND RASIIO FLOCRS}

These "sort composition" floors cue sold under various trade names and, in general, have ro base of sphalt, bitumen or resin. clemers cind polishes contoining abrasives, oils or organic

solvents (gasoline, turpentine, carbon tetruchioride, etc.) should not be used. These floox should be washed by mopping with a neutral soap and Iulewam soft woter. Scrubbine maines with soft polishing brushes hovo boen usoc for lngo areas. After cleaning and ryine, these floorings (especially the asphalt tile) aro goncro.ly wxed in ordor to covor the surfaco with a protoctive filin. The ater-omision tayes (sce p. froe from oils and volatilo orgenic solvents aro the safest vexes to usc on those floorings. This type of max can bo applied with a cotton cloth mop or wool applicator. The we should be sprese as thinly as possible on tie surface of the floor, using the mop or applicator in oro diroction only. In a short time the war should dry to a hard, lustrous finish.

Asphalt tile floors should not be buffed or burnished until the wex or othor trestiont is complotely dry. The troated floors may be maintained by swoping rith a brush, a dry mop, or by buffing with mechanical buffers. Scrubbing with water and a noutral soap nay be roquired at times (probably two or throc times a joar). Dils, soaps or othor detergents contrining abrasives, ana sweeping compounds containing Irce oil should not be usce on the untreated or the troated floors. The floor treathonts should bo renuwed at intervols, depending upon the severity of wear.

Before treeting an asphalt tile floor with an unknown preparation, moisten a wite cloth vith the preparation and rub over tho surfeco of one tile. If the color of the tile shoms on the cloth it indicates that the solvent in the preparation has dissolved part of the surface of the tile and shors conclusively that the preparation would not be safe to use. It would be safer to cit the advice of the manuracturer of the flooring before using unknown cleaning preparations.

\section{PLASTIC VAGNESIA OEUENT FLOORS}

These floors contain wesnesin oxychloride as the cenenting material and are known by various names ("Sorel cement", "Fard Composition", "Magnesite", "woodstone", etc.) Thcse flórs may be cleaned by first wettine with clear' water and then mopping with d noutral soap cnd varm sort ator (a solt soep, such as a linseed oil-potash scap is oftan uned). After clcaning and drying, the lloors wiy be given a protective coating offrax (watermax 
emulsion) or of special varnish or lacquer. The truated floor may be cleaned by sweeping with a dry nop or soft brush, and occosionol washing, and buffing with o weighted brush or polishing wanine. Tho waxing or other treatment is rencued as conditions requiro.

\section{KIII. SIALE TIIE FLOORS}

These floors may be oleaned by fopping with a neutral soap (avpaste soap is often usod) and varn soft water. After cleaning and drying, the foors my be waxed with a water-wax emulsion or given a coat of pale varnish or lacquer. The treated floor can be kept in Eood condition by sweeping ith a dry mop or soft brush, and an occasional buffing with a weighted brushed or polishing machire.

\section{XIV。 PEFEREITES}

Rubber Rlooring Manufacturers Division, The Rubber lianufacturers Association, Inc., 250 W. 57th St., New York, iv.Y. "Approved Maintenance Lethods for Rukber Floors" (1932)

Management Division, The Real Estate Board of New York, Inc., Real Estate Board Bldg., New York, N.Y. Mleaning Princiules and Practices". (1931)

Holcombe, Paul E., "A Study of Floors", National Association of Builojing Ownoms. and lanagers, Chicago, III. Brenn, J.I., "Lodern Floor Laintenance". Soap I, No. I1, pp. 97,
99, IOI, I931

Educational Bureau, Scientiric Seçtion, Paint and Varnish Manufacturers' Association of the Unjted States, Washington, D.C., Circular Ho. 161. "Household Care of Iinoleum and Similar Floor Coverings" (1922).

KeIly, $\dot{A}$. Ashmun, "Ihe Expert Wood Finisher". Press of the Master Painter Publishing Company, Malvern, Pa. (1912) 


\section{Government Publications}

(The puolications for whjoh prices are indicated moy be purchased from the Superintendent of Documents, Government Printine Office, Washington, D.C. Renittance should be mado by coupons (which way be purchased from the Superintendent of Docuncnts in sets of 20 for 1.00$)$, postal money ordor, express order, or liew York draft payabic to tho "Superintendent of Documonts, Government Pinting Office, Washington, D.C." Curiency may be scrt at sender's risk. Postage stamps, defaced or smooth coins, or foreign money positively will not be accepted. Publications are torrarded under Government frank to addresses in the United States and its possessions; clso to Mexico and Conada. The publications not priced nay be obtained directly from the Bureau of Standards.)

Haterials for the Household. B.S. Circujar c-70. $50 \phi$ Washing, cleaning and polishing materials. B.S. Oircular $\mathrm{C}-383.10 \%$

Safety for the househola. B.S. Circular C-397. 15ф

Floors and floor coverings. U.S. Department or Agriculture Farmersi Bulletin No, 1219. $5 \phi$

Housecleaning made easier. U. S. Department of Agriculture Farmers' Bulletin No. II80. $5 \not \dot{~}$

Acid-proof coatings for concrete surfaces. B. S. Letter Circular LC-42

Report of service tests on concrete floor treetments. B.S. Letter Circular LC-139.

Rubber floor tile. 3.S. Lotter vircular LC-270.

Polishes. B.S. Letter Circuler LC-275 
Foúr I Spowiontons for Ditorgonts

Spec. Syinbol.

Literial

Price

$p-p-591$

Powdor, Scouring (fror) Hloors

P-S-55I

Soap, automobilo

$p-S-566$

Soap, chip

$P-S-571$

Soap, git, curo

P-S -576

Soap, frit, hand

$\mathrm{P}-\mathrm{S}-586$

Soap, Iawidry, Iiquid

P-S -591

Soap, launary, ordinary

$\mathrm{P}-\mathrm{S}-596$

soap, laundry, powdored

$5 \phi$

P-S - 618

Soap, Iiquid

P-S-606

Sozip, powder

P-S-611

Soap, salt mater

$5 \not$

$5 \%$

$5 \phi$

$P-5-6 I 6$

Soap, toilut, floatine, white

P-S-62].

Sosp, toilct, nilled

P-S -631

Soda, cisustic (Iye)

P-S-64I

Sode, laundry (woshing soda)

$5 \phi$

$5 \phi$

$5 \phi$

$0-5-571$

Soda a.sh

$5 \phi$

$5 \%$

$0-5-501$

Sodium carbonate, arnnular (monohydrate crystals)

$5 \phi$

$5 \%$

$5 \phi$

$5 \%$

$5 \phi$

$0-7-671$

Trisodium phosphote, technical

(phosphote eleancr) 